Original research article

\title{
Quality of life in patients with chronic heart failure
}

\author{
Pavla Kudlová ${ }^{1 *}$, Ilona Kočvarová ${ }^{2}$, Kateřina Burešová ${ }^{1,3}$ \\ ${ }^{1}$ Tomas Bata University Zlín, Faculty of Humanities, Department of Health Sciences, Zlin, Czech Republic \\ 2 Tomas Bata University in Zlin, Faculty of Humanities, Research Center, Zlín, Czech Republic \\ ${ }^{3}$ Faculty Hospital in Olomouc, 1st Internal Medicine Clinic - Cardiology Department, Olomouc, Czech Republic
}

\begin{abstract}
Goals: Our goal was to establish the level of life quality in patients with chronic heart failure (CHF), and to find out whether there was a connection between their gender, socio-demographic status, BMI, number of comorbidities, NYHA class, treatment regime, time of treatment, age, and quality of life.

Methods: This research was conducted in 2018 at cardiology outpatient wards in patients with CHF using the standardized Minnesota Living with Heart Failure Questionnaire (MLHFQ). In order to perform complex monitoring of the relations among the variables within the study we conducted regression analysis, however, in exploratory regime as a descriptive technique, and so regardless of the value of statistical significance, and without an attempt to generalize. The model was realized using the ENTER method. Our goal was to include all of the above variables in it. We then estimated the relative power of influence using a standardized beta coefficient.

Results: Based on the values of this coefficient we can say that an increasing NYHA class, and being a male disabled retiree has the most significant influence on life quality. Adherence to the treatment regime does not have a significant impact on life quality; in fact, strict adherence to it may even result in its worsening.

Conclusions: For patients with a different NYHA class, treatment goals may differ. It is important for them to be aware of the fact that even if adherence to the treatment regime interferes with their quality of life, adherence to it is necessary in order to slow down the progress of this serious disease.
\end{abstract}

Keywords: Chronic heart failure; MLHFQ; Patient; Life quality; Regime measure

\section{Introduction}

Chronic heart failure (CHF) is a syndrome of heart disease, in which despite adequate filling of the ventricles, cardiac output per minute decreases and the heart is not able to cover the metabolic needs of the tissues. Manifestations of CHF without a drop in cardiac output might occur during inadequate increase of filling pressure of the ventricles. In order to diagnose $\mathrm{CHF}$, there must be symptoms, evidence of heart failure, and objectively proven impairment of heart functioning (Špinar et al., 2012).

Chronic heart failure is a complex clinical syndrome that affects patients with various cardiovascular diseases. It has severe consequences, significantly decreases lifespan, and has a negative impact on life quality (Málek and Schejbalová, 2011). It is the final stage of almost all cardiovascular diseases, and is a significant cause of morbidity and mortality (Riedel, 2009, p. 407). The clinical picture shows mainly dyspnoea, cough, fatigue, ineffectiveness, peripheral edema, stenocardia (Špinar et al., 2012); and in an advanced state also depressions and deliriums - especially in older patients, development of cardiac cachexia with muscle loss, incontinence, self-care deficit, etc. (Halmo et al., 2015).
To specify the severity of CHF, NYHA classification (criteria processed by the New York Heart Association), ejection fraction or sodium level are generally used (McMurray et al., 2012; Widimský et al., 2013). Treatment of CHF must be complex, which includes a whole range of non-pharmaceutical measures, pharmacotherapy, and in indicated cases various kinds of surgery (Hradec and Býma, 2015; Špinar et al., 2012).

The prevalence of patients with $\mathrm{CHF}$ in the Czech Republic (CR) is estimated to be between 100,000 and 200,000 with approximately 40,000 new cases appearing annually. Thanks to increasingly effective treatment, mortality has been significantly limited to mostly acute cardiovascular complications. Despite this, the surviving patients have a more or less affected myocardium, and CHF gradually develops in them. Approximately $50 \%$ of them die within 5 years of being diagnosed. Patients with CHF are very often polymorbid, usually older, of female gender, obese, with hypertension and diabetes mellitus (Hradec and Býma, 2015; Vojáček et al., 2017).

CHF decreases lifespan, affects all domains of life quality, and thus has an impact on physical health, health condition, the patients' environment, and social relations. Despite this, patients often underestimate the severity of their condition and adherence to the recommended treatment regime (Luo et al., 2019; Obiegło et al., 2017).

\footnotetext{
* Author for correspondence: Pavla Kudlová, Tomas Bata University Zlín, Faculty of Humanities, Department of Health Sciences, Štefánikova 5670, 76001 Zlín, Czech Republic; e-mail: kudlova@utb.cz http://doi.org/10.32725/kont.2019.050 
Adverse health condition might lead to repeated hospitalizations, disability, and financial inadequacy. Physical symptoms, adverse effects of treatment, disease, but also financial inadequacy might decrease life quality by up to $40 \%$ (Hopp et al., 2010; Luo et al., 2019; Volz et al., 2011). Decreased life quality in patients with CHF is connected to depressions (Bunyamin et al., 2013; Vévodová et al., 2017). Effective education of the patient and his/her family members may improve collaboration and increase adherence to treatment. In a similar fashion, effective nursing management and self-management of the patients with CHF may decrease the number of hospitalizations, improve the condition and life quality in patients with CHF, and decrease costs of their treatment (Abbasi et al., 2018; Ghanbari-Firoozabadi et al., 2014; Hradec and Býma, 2015; Mainardi et al. 2006; Travis et al., 2012).

Our task was to establish the level of life quality of our respondents using the MLHFQ, and find out whether there is a connection between their gender, socio-demographic status, BMI, the number of comorbidities, degree of NYHA, treatment regime, length of disease/treatment, age, and life quality. In order to do this we set three goals.

\section{Goals}

1. To find out whether the patients adhere to basic treatment measures in connection to $\mathrm{CHF}$

2. To establish life quality in patients with $\mathrm{CHF}$ in the past month using the MLHFQ

3. To find out if there is a connection between their gender, socio-demographic status, BMI, the number of comorbidities, NYHA degree, treatment regime, time of treatment, age, and quality of life (MLHFQ).

\section{Materials and methods}

We applied an innovative quantitative research technique using a questionnaire composed of three parts. Part 1 focused on socio-demographic data (gender, age, height, weight, duration of treatment, socioeconomic position, and dyspnoea assessment according to NYHA) - a total of 7 items; Part 2 standardized Minnesota Living with Heart Failure Questionnaire (MLHFQ) - a total of 21 items; Part 3 - focused on adherence to treatment measures - a total of 10 items; time to fill out the questionnaire - 20 minutes.

The standardized MLHFQ is focused on individual symptoms of heart failure that have affected the patient's (respondent's) life quality in the past month. Each item is assessed using a six point Likert scale ranging from 0 to 5 (zero $=$ no limitation, 5 = maximum limitation). The MLHFQ was written in 1984 by Thomas S. Rector and Jay N. Cohn from the Cardiovascular Center with the University of Minnesota. A onetime license to the MLHFQ was provided by the University of Minnesota (Office for Technology Commercialization) for the purpose of this study (Rector, 2017, p. 4).

The MLHFQ score was summarized based on assessment criteria from 21 questions. The number of points the respondents could get was from 0 to 105; the higher the score, the greater the limitation of the patient with CHF. Physical score is assessed based on items $2,3,4,5,6,7,12,13$ as a sum of points from individual items. The value of physical score ranges between 0 and 40 ( 0 means no limitation, 40 maximum lim- itation). The emotional aspect is presented by items $17,18,19$, 20,21 . The emotional score ranges from 0 to 25 ( 0 means no limitation, 25 maximum limitation) (Rector, 2017, p. 6).

The survey took place between April 2018 and September 2018 in cardiology outpatient wards in patients with CHF.

\section{Characteristics of the survey pool}

The questionnaire could be filled out by: patients treated in heart failure outpatient wards, patients treated with $\mathrm{CHF}$ for at least one year, adult patients with NYHA I-IV (New York Heart Association - classification of dyspnoea in patients with CHF), BMI was calculated based on actual measurements of height and weight at the outpatient ward, and the respondents were willing to fill out this anonymous questionnaire.

\section{Organization and data processing}

Once the permission of the respective medical facility was granted, the patients that met the criteria and competent persons (nurse practitioners) from the selected outpatient wards were asked for cooperation. At the outpatient wards the patients were informed of the goals of the study and how to fill out the questionnaire. Then their height and weight were taken, and their current status within the NYHA classification verified. The BMI (body mass index) was calculated based on the formula [weight (kg)/height (m)]. The NYHA criteria processed by the New York Heart Association were used to assess heart failure: I. No limitation of physical activity. Normal effort does not result in feelings of exhaustion, dyspnoea, palpitation or angina pectoris; II. Slight limitation of physical activity. Normal effort leads to exhaustion, dyspnoea, palpitations or angina pectoris; III. Serious limitation of physical activity. Even little effort leads to exhaustion, dyspnoea, palpitations or angina pectoris; IV. Problems with any kind of physical activity leading to the patient's disability. Dyspnoea, palpitations or angina pectoris appear even without performing any physical activity (McMurray et al., 2012; The Criteria Committee of the New York Heart Association, 1994, pp. 253-256). The patients filled out the questionnaires in waiting rooms with plenty of time to do so.

It is an exploratory study using an intentional pool of respondents who had to meet the given criteria in order to be allowed to partake in the study. Procedures of inference statistics were intentionally not applied within the analysis, instead measures of material significance were used as these are crucial for applying the results in practice, and are independent of the representativeness and size of the research pool (Soukup, 2013).

\section{Results}

282 respondents partook in the survey, of which 174 were men $(62 \%)$ and 108 women (38\%), aged 22 to 80 (average age of $53, S D=15.2$ ). More detailed characteristics of the respondents and their division based on gender are shown in Table 1.

Only 26 respondents (10\%) had a BMI within normal range, 117 (i.e. 45\%) were overweight, and 115 (i.e. 45\%) were obese.

The NYHA degree (New York Heart Association - classification of dyspnoea) was verified for the respondents based on their current condition at the outpatient ward - Table 2. 
Table 1. Characteristics of the pool

\begin{tabular}{lcccc|cccccccc} 
& \multicolumn{4}{c}{ Male } & \multicolumn{4}{c}{ Female } & \multicolumn{4}{c}{ Total } \\
\cline { 2 - 13 } & $\bar{x}$ & Min & Max & $S D$ & $\bar{x}$ & Min & Max & $S D$ & $\bar{x}$ & Min & Max & $S D$ \\
\hline Age & 56.5 & 22.0 & 80.0 & 15.9 & 47.6 & 24.0 & 76.0 & 12.1 & 53.1 & 22.0 & 80.0 & 15.2 \\
Weight & 92.5 & 65.0 & 121.0 & 13.1 & 80.0 & 54.0 & 103.0 & 15.2 & 87.8 & 54.0 & 121.0 & 15.2 \\
Height & 176.0 & 160.0 & 191.0 & 6.8 & 165.0 & 153.0 & 180.0 & 8.3 & 171.8 & 153.0 & 191.0 & 9.2 \\
BMI & 29.88 & 23.88 & 40.56 & 4.09 & 29.27 & 22.60 & 38.21 & 4.73 & 29.65 & 22.60 & 40.56 & 4.35 \\
Total no. of & 3.7 & 1.0 & 10.0 & 1.9 & 3.6 & 0.0 & 9.0 & 1.8 & 3.7 & 0.0 & 10.0 & 1.9 \\
comorbidities (0-10) & & & & & & & & & & & & \\
Treatment duration & 5.9 & 1.0 & 21.0 & 4.4 & 4.1 & 1.0 & 11.0 & 2.8 & 5.2 & 1.0 & 21.0 & 3.9 \\
\hline
\end{tabular}

Table 2. Assessment of dyspnoea in the respondents according to NYHA

\begin{tabular}{rrrrrrrr} 
& & \multicolumn{6}{c}{ Gender } \\
\cline { 3 - 8 } & \multicolumn{2}{c}{ Male } & \multicolumn{2}{c}{ Female } & \multicolumn{2}{c}{ Total } \\
\cline { 2 - 8 } & & \multicolumn{1}{c}{$\%$} & \multicolumn{1}{c}{$N$} & \multicolumn{1}{c}{$\%$} & \multicolumn{1}{c}{$N$} & $\%$ \\
\hline \multirow{4}{*}{ NYHA } & 1 & 26 & 14.9 & 33 & 30.6 & 59 & 20.9 \\
& 2 & 71 & 40.8 & 46 & 42.6 & 117 & 41.5 \\
& 3 & 58 & 33.3 & 22 & 20.4 & 80 & 28.4 \\
& 4 & 19 & 10.9 & 7 & 6.5 & 26 & 9.2 \\
\hline
\end{tabular}

\section{Respondents' socioeconomic position}

Regarding our respondents' socioeconomic position - 54 (i.e. 19.1\%) were employed, 23 (i.e. 8.2\%) unemployed, and 80 (i.e. $28.4 \%$ ) were disabled (without specifying degrees of disability); 96 (34.0\%) retired, 19 (6.7\%) self-employed, and 10 respondents (i.e. $3.5 \%)$ stated other.

Twenty respondents (7.1\%) stated disability of the first degree, 37 (13.1\%) disability of the second degree, and 23 (8.2\%) disability of the third degree. Most of the respondents with disability of the first and second degree were women (46 women, 11 men); while there were significantly more men with disability of the third degree (19 men, 4 women).
Results to Goal 1: To discover whether the patients adhered to basic treatment measures for CHF.

For each item (No. 7-16) the respondents could get $0-2$ points. The more points, the better the patient adheres to the treatment regime. A sum index was subsequently created from the items that could reach up 0-20 points. The results are shown in Table 3 .

\section{Score of adherence to the treatment regime by the respondents}

The maximum number of points was 20, with respondents reaching at least 15 points ( $75 \%)$ considered as those adhering to the treatment regime. 31 respondents reached 15 or more points $(11 \%)$.

Results of Goal 2: To find out what the life quality of the respondents with $\mathrm{CHF}$ had been like in the past one month according to the MLHFQ.

Individual MLHFQ items are shown in Table 4.

The total mean score according to the MLHFQ was $47.96 \pm$ 19.86 (40.88 in women, 52.35 in men). The total average emotional score according to the MLHFQ was $10.50 \pm 5.39$ (8.95 in women, 11.45 in men). The total mean physical score based on the MFHFQ was $19.19 \pm 7.43$ (16.44 in women a 20.90 in men).

Table 3. Adherence to treatment measures in the respondents

\begin{tabular}{|c|c|c|c|c|c|c|}
\hline & Min & Max & Mean & $S D$ & Median & Modus \\
\hline 7. Regular weight checks & 0 & 2 & 0.76 & 0.71 & 1 & 1 \\
\hline 8. Regular use of only physician-prescribed medicines & 1 & 2 & 1.75 & 0.43 & 2 & 2 \\
\hline $\begin{array}{l}\text { 9. Increased doses of diuretics after sudden increase of } \\
\text { weight }>2 \mathrm{~kg} / 3 \text { days (or contacting attending doctor) }\end{array}$ & 0 & 2 & 1.02 & 0.98 & 1 & 2 \\
\hline 10. Decreasing salt intake $<4-5 \mathrm{~g} \mathrm{NaCl} /$ day & 0 & 2 & 1.04 & 0.76 & 1 & 1 \\
\hline 11. Elimination of foods with great salt content & 0 & 2 & 0.56 & 0.72 & 0 & 0 \\
\hline $\begin{array}{l}\text { 12. Adherence to daily intake of liquids according to } \\
\text { physician's recommendation }\end{array}$ & 0 & 2 & 1.59 & 0.75 & 2 & 2 \\
\hline $\begin{array}{l}\text { 13. Modest consumption of alcohol (if not counter- } \\
\text { indicated) }\end{array}$ & 0 & 2 & 1.54 & 0.75 & 2 & 2 \\
\hline 14. Strict smoking ban & 0 & 2 & 1.00 & 0.79 & 1 & 1 \\
\hline $\begin{array}{l}\text { 15. Adequate physical exercises in respect to the degree } \\
\text { of NYHA and physician's recommendation }\end{array}$ & 0 & 2 & 1.01 & 0.92 & 1 & 2 \\
\hline $\begin{array}{l}\text { 16. Reduction of weight in overweight and obese } \\
\text { patients }\end{array}$ & 0 & 2 & 0.49 & 0.86 & 0 & 0 \\
\hline Total number of points for items $7-16$ (0-20 points) & 1 & 18 & 10.76 & 3.85 & 11 & 10 \\
\hline
\end{tabular}


Table 4. Individual items of the MLHFQ (the higher the mean, the greater the suffering)

\begin{tabular}{|c|c|c|c|c|c|c|}
\hline & Min & Max & Mean & $S D$ & Median & Modus \\
\hline 17. Swollen ankles & 0 & 5 & 2.28 & 1.07 & 2 & 2 \\
\hline 18. The need to sit or lie down to rest during the day & 1 & 4 & 2.57 & 0.95 & 2 & 2 \\
\hline $\begin{array}{l}\text { 19. Difficulties while strolling or walking upstairs } \\
\text { (dyspnoea, fatigue) }\end{array}$ & 1 & 5 & 2.84 & 1.17 & 3 & 2 \\
\hline $\begin{array}{l}\text { 20. Difficulties while working around the house or } \\
\text { garden }\end{array}$ & 1 & 5 & 2.66 & 1.02 & 3 & 2 \\
\hline 21. Limitations going for walks outside & 0 & 5 & 1.94 & 1.34 & 2 & 3 \\
\hline 22. Disrupted sleep at night & 0 & 5 & 1.82 & 1.38 & 2 & 2 \\
\hline $\begin{array}{l}\text { 23. Limitations in performing joint activities with } \\
\text { friends or family }\end{array}$ & 0 & 5 & 2.03 & 1.27 & 2 & 3 \\
\hline 24. Limitations in the possibility to earn money & 0 & 5 & 2.31 & 1.92 & 2 & 0 \\
\hline $\begin{array}{l}25 \text {. Limitations in performing hobbies, sports and } \\
\text { recreational activities }\end{array}$ & 0 & 5 & 2.52 & 1.47 & 2 & 3 \\
\hline 26. Limitations in sexual life & 0 & 5 & 2.83 & 1.77 & 3 & 4 \\
\hline 27. Limitations in eating (eating less than was usual) & 0 & 5 & 2.35 & 1.03 & 2 & 3 \\
\hline 28. More pronounced breathing & 1 & 5 & 2.83 & 1.09 & 3 & 2 \\
\hline 29. Fatigue, exhaustion or lack of energy & 0 & 5 & 2.51 & 0.97 & 3 & 2 \\
\hline 30. Recent hospitalization & 0 & 5 & 1.46 & 1.56 & 1 & 0 \\
\hline $\begin{array}{l}\text { 31. Impression of financial difficulties connected to } \\
\text { medical care being provided }\end{array}$ & 0 & 5 & 2.33 & 1.19 & 2 & 2 \\
\hline 32. Adverse effects of medicines & 0 & 5 & 2.18 & 1.42 & 2 & 2 \\
\hline 33. Feelings of being a burden to family or friends & 0 & 5 & 2.12 & 1.30 & 2 & 3 \\
\hline 34. Feelings of loss of self-sufficiency & 0 & 5 & 2.12 & 1.28 & 2 & 2 \\
\hline 35. Growing fears of the future & 0 & 5 & 2.46 & 1.41 & 2 & 3 \\
\hline 36. Growing difficulties with memory and concentration & 0 & 5 & 1.80 & 1.47 & 2 & 0 \\
\hline 37. Feelings of anxiety and depression & 0 & 5 & 1.99 & 1.13 & 2 & 3 \\
\hline
\end{tabular}

Results of Goal 3: To find the relationship between gender, socio-demographic status, BMI, the number of comorbidities, NYHA degree, treatment regime, time of treatment, age, and quality of life.

The last goal is focused on a complex monitoring of the relationships between the variables monitored within the study. Regression analysis was conducted to reach this goal, however, only in exploratory regime as a descriptive technique, and so without regard to the values of statistical significance and without an attempt to generalize them (Mareš et al., 2015, p. 341); on the contrary with emphasis on measures of material significance (Soukup, 2013). The model was carried out using the method ENTER, our goal being to include in it all the below mentioned variables.

Life quality was included in this model as a dependent variable (in the sense of the total number of points in the MLHFQ, when an increasing number of points means an increasing limitation to life quality caused by heart failure).

As independent variables we included: the respondents' gender, socioeconomic position, BMI (found to be between 22.6 and 40.6 in the pool), number of comorbidities (0-10 total), degree of NYHA (1-4), total level of adherence to the treatment regime (sum index based on items 7-16 theoretically reaching 0-20 points), treatment duration in years (found to be between 1-21 years in the pool), age in years (found to be $22-80$ years in the pool).

\section{Result}

Due to multicollinearity (tolerance value $\leq 0.2$; VIF value $\geq 5$ ) we merged 2 variables in the model relating to socioeconomic position: disability (without specifying the levels) and retirees. We did not include respondents who stated their socioeconomic as 'other' as it would add the element of indefiniteness, which was not desired, and also because it was the least numerous group of respondents. There were ten such respondents. So we worked with 272 respondents, thus complying with basic recommendations as to the size of the pool (Mareš et al., 2015, p. 357).

The resulting model of regression analysis was $(F=75.991$; $\mathrm{df}=13$; sig. $<0.0005 ; R^{2}=0,79$; adjusted $\left.R^{2}=0.78\right)$. While using our spectrum of independent variables we are able to explain $78 \%$ of the dispersion of dependent variable, which is a very good result.

The model below will help us to estimate the influence of every independent variable on dependent variable (while controlling the function of the other independent variables), using nonstandardized regression coefficients $B$. We then estimate relative strength of influence (in comparison to the other variables) using standardized coefficient beta.

The other values in Table 5 (Std. Error, t, Sig.) are pointless for our purposes because we do not generalize, but work only at the descriptive level. 
Table 5. Regression analysis model

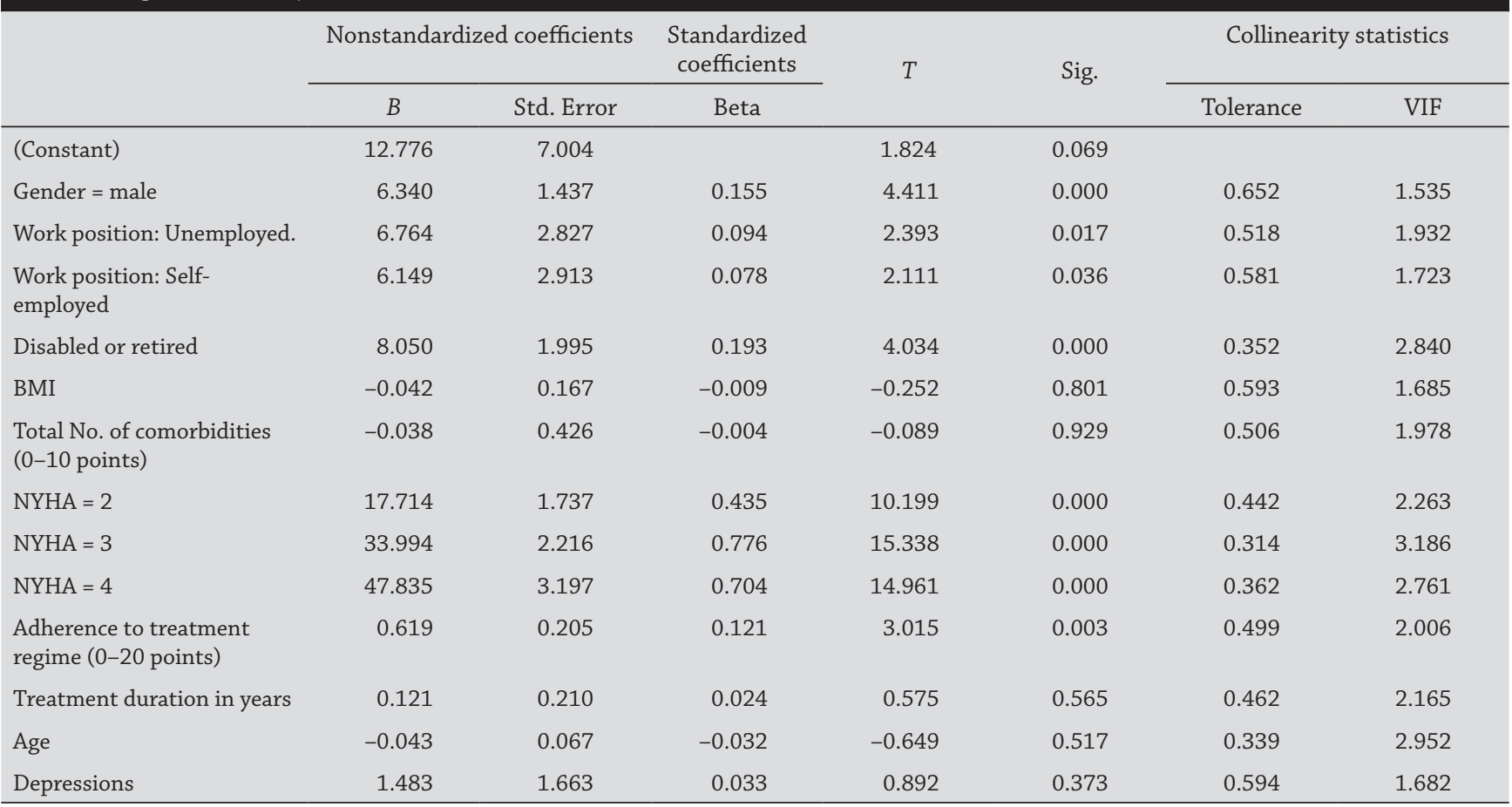

Interpretation of coefficients $B$ :

- Men achieved 6.3 points more in the MLHFQ than women, while controlling the other independent variables.

- Unemployed respondents achieved 6.7 points more in the MLHFQ; self-employed 6.1 points more; disabled or retired respondents 8.0 points more than employed respondents, while controlling the other independent variables.

- The degree of NYHA is very important. Respondents with NYHA class 2 achieved 17.7 points more; those with NYHA class 3 achieved 33.9 points more, and those with NYHA class 4 achieved 47.8 points more compared to those with NYHA class 1.

- If the respondents stated that they suffered from depressions, they had on average 1.8 points more than the other respondents. This influence was very weak.

- The BMI, the number of comorbidities, adherence to treatment regime and age had a negligible or very weak influence.

Interpretation of standardized coefficients beta:

Based on the values of this coefficient we can say that according to the MLHFQ, an increasing NYHA class has the most significant influence on the patients' life quality, followed by being disabled or retired, and being a man. Only then do the other categories specified in the model play a role.

\section{Discussion}

The survey took place in specialized outpatient wards focused on heart failure (HF). The sample was made up of 282 respondents, of which 174 (62\%) were men and 108 (38\%) were women. According to Hradec and Býma (2015) and also the recommended procedure of the $C$ zech Cardiology Society there are 100,000-200,000 patients with CHF in the Czech Republic, and roughly the same number of patients with asymptomatic systolic dysfunction of the left ventricle, most of whom eventually end up in the stage of manifesting HF. Incidence of HF exponentially rises with every decade. The average age of patients with CHF is between 74 and 76 (Hradec and Býma, 2015; Špinar et al., 2012). According to the Framingham study, prevalence of HF in the people under 60 years of age is $0.8 \%$, in people aged $60-69$ years $2.3 \%$, and in people over 70 years of age $9.1 \%$ (Greenberg et al., 2010). The average age of the respondents in our study was 53 years $(S D=15.2)$; the women were on average 48 years old, the men 56 . Thus our respondents were relatively young for patients with $\mathrm{CHF}$. Average treatment duration was 4.1 years in the women and 5.9 years in the men.

Based on the recommendation of the Czech Cardiology Society and the Society of General Medicine, ČLS JEP patients with $\mathrm{CHF}$ must be instructed regarding the necessity to monitor symptoms of the disease and trimming body weight, and adherence to regime measures (Hradec and Býma, 2015). In our study, only 31 respondents (11\%) achieved 15 or more points, most of them women - see Table $3.90 \%$ of the patients were found to be overweight or obese, the BMI was between 22.6 and 40.6, with the average of $29.6(S D=4.3)$. Average BMI in women was 29.3, in men 29.9 (overweight at the top limit). In spite of that the respondents failed to reduce weight within the treatment measures.

It is not easy to define life quality, and there is still no agreement on a definition. Besides the feeling of physical health it also includes mental condition, social position, religious and economic aspects. Life quality reflects the level of personal wellbeing, the ability to take care of oneself, one's mobility and the ability to influence his/her own life (Slováček et al., 2004). However, experts agree that life quality is viewed as a multidimensional magnitude. The goal of HF treatment is to increase life quality, i.e. to decrease or completely remove its symptoms, to increase load tolerance, decrease mortality, and extend the patients' lifespan (Lewis et al., 2001). However, for each patient the order and importance of these goals may be different. For patients that are a little symptomatic, decreasing 
mortality and slowing down regression of the disease is a priority. For severely symptomatic patients, however, it is more important to be relieved from their health problems, and their life quality improved. CHF is not manifested only with physical symptoms. This disease also has a significant impact on the mental, social and economic areas. Patients with CHF live in a state of neverending limitations, without visible reward because CHF cannot be cured. Despite this, it is possible to slow its progressions through adherence to the treatment regime (Špinar et al., 2012).

Advanced heart failure means that patients, despite undergoing adequate therapy, have reached NYHA class III, or even NYHA class IV (Lazárová et al., 2012). In our study we had $33.3 \%$ men and $20.4 \%$ women in NYHA class III, and $10.9 \%$ men and $6.5 \%$ women in NYHA class IV. Caring for patients with $\mathrm{CHF}$ is demanding due to a number of comorbidities connected to this disease, which often require multidisciplinary collaboration (anemia, renal insufficiency, lung function or liver function impairment, hypothyreosis, depressions, etc.) (Lazárová et al., 2012). In our study we had 0-10 comorbidities with an average number of 3.6 in women and 3.7 in men. The most common were dyslipidemy (203 cases), diabetes mellitus (155 cases), liver disease (134 cases), anemia (77 cases), lung disease (60 cases), and depressions ( 74 cases), while the number of comorbidities had a negligible influence on life quality measured by the MLHFQ. If it increases by 1 , the number of points in the questionnaire increases by 0.1 .

The authors of this explorative study, Boman et al. (2017), reached the conclusion that it was anemia, not a lack of iron, that is connected to clinical symptoms and life quality in patients with severe heart failure and palliative home care.

In the past two years there has been a lot of evidence supporting the importance of psychological variables for the prognosis and life quality in patients with CHF. Multiple studies have proven that it is namely depression that has a negative influence on mortality (Volz et al., 2011). According to Vévodová et al. (2017), impaired life quality in patients with CHF has to do with depression, which is diagnosed in up to $36.5 \%$ of them. We cannot fully compare our results to those because they used a different measuring tool to measure life quality (the WHOQOL-BREF questionnaire), and worked with a significantly smaller survey sample (110 respondents at cardiology wards of three hospitals in the Czech Republic), from which it is impossible to generalize - even though confirmation regime with hypotheses and statistical tests was applied in the study. However, our study also suggests that depressions are connected to life quality, but the connection is very weak. The study by Fotos et al. (2013) concludes that the mean life quality corresponds to 62.7 points. The mean life quality of our respondents corresponded to 44.6 points (Fotos et al., 2013). The closest to our results was Ms. Šenkyříková's MLHFQ result (2014, p. 55), concluding that mean life quality corresponded to 44.9 points. A study by Buleu et al. (2019), showed a strong correlation between a lack of vitamin $\mathrm{D}$ in patients with $\mathrm{CHF}$ and the severity of heart failure, decrease in life quality, anxiety and depression. However, it is necessary to continue with the research.

Based on our survey, we can conclude that a higher NYHA class has a significant negative influence on life quality. The influence of the BMI turned out to be negligible in our analysis.

The influence of adherence to medical procedures is very weak and negligible according to our study. On top of that it is slightly negative. The biggest problem is to keep motivating the patient to adhere to the treatment regime in the long run even when it does not have a visible effect. This gives rise to an inconsistency between what the patient wants to do and what he has to do.

The study by Heo et al. (2015) focused on the knowledge of factors that can be influenced, adherence to dietary measures, and social support connected to life quality. This study proved that interventions focused on deepening the knowledge of factors that can be influenced may lead to improving control over heart failure, and thus increasing life quality (Heo et al., 2015). Our survey, just like the survey by Haluzíková and Hrubá (2015), did not turn out so positive (in the monitored areas of adherence to the treatment regime - regular application of prescribed medicines and adherence to dietary measures, and reducing the risk factor of smoking). The authors concluded that the patients relied more on medicines and assistance provided by physicians and nursing staff than making their own effort to change their lifestyle and adhere to regime measures.

By adhering to the treatment regime the patient loses part of his/her own autonomy. $\mathrm{He} / \mathrm{sh}$ must adhere to a number of strict limitations and bans (salt, alcohol, smoking, etc. see Table 3), and needs a balanced regime with plenty of rest, which concerns all kinds of activities - physical, mental, sexual and other. The scale of limiting the patients' activities depends on the scale of ventricular dysfunction and severity of the symptoms. With regard to one's individual situation it is necessary to consider disability pension for many patients with NYHA class III-IV (Špinar et al., 2012). In our study, there were 23 (8.2\%) unemployed people, a total of 80 (28.4\%) disabled respondents (regardless of disability level), 96 retirees $(34.0 \%)$, and a total of 19 (6.7\%) self-employed respondents. Self-employed respondents scored 6.1 points more in the MLHFQ; unemployed 7.0 points more; disabled or retired respondents 8 points more compared to employed respondents, while controlling other independent variables. Both our and foreign findings confirm that losing a job or disability may lead not only to worse life quality and a worse living standard, but also to a whole scale of other negative personality changes (decreased self-confidence, self-esteem, feelings of uselessness and hopelessness). Unemployment is considered as a key socioeconomic determinant of health (Buchtová et al., 2002; Kliková and Kotlán, 2003).

Adherence to the treatment regime is not just about correct application of pharmacotherapy and adherence to the regime measures, but also about active continual work with the patient's environment and his/her own personal motivation. Thus far we do not work with support from the side of persons with the same disease and their personal experience in this country.

\section{Conclusions}

The current CHF therapy is focused not only on influencing the symptoms, it also tries to influence the progression of heart failure and decrease mortality. Despite that, treatment goals might be different for a physician and a patient with any NYHA class. The survey showed that it is an increasing NYHA class that has the greatest influence on life quality in accordance to MLHFQ, followed by being disabled or retired, and being of male gender. Adherence to the treatment regime does not have a significant influence on life quality. On the contrary, extreme adherence to it might even lead to its worsening. Despite this, it is important for the patient to realize that adherence to treatment measures is necessary in order to slow down the progression of this serious disease. 


\section{Limitations of the study}

A limitation of the study was its regional reach, thus the results cannot be generalized. Another limitation might be a lower average age of our respondents in comparison to presumed incidence in the population, and the fact that there were a lot more men in the pool - 174 men (62\%) and 108 women (38\%).

\section{Acknowledgements}

We thank our colleagues for their support and all of the patients for their collaboration.

\section{Conflict of interests}

The authors have no conflict of interests to declare. The study was approved by appropriate commission. All of the patients were informed in the introductory part of the questionnaire that their participation was voluntary. This work, as part of project "Multidisciplinary approaches to chronic disease", was supported by RVO excelent/ MSM - RVO/FHS/2019/003.

\section{Kvalita života u pacientů s chronickým srdečním selháním}

\section{Souhrn}

Cíle: Naším úkolem bylo zjistit u pacientů s chronickým srdečním selháním (CHSS) míru kvality života a zda existuje vztah mezi pohlavím, sociodemografickým postavením, BMI, počtem komorbidit, stupněm NYHA (kritéria vypracovaná New York Heart Association), léčebným režimem, dobou léčení, věkem a kvalitou života.

Metodika: Výzkum byl realizován v roce 2018 na kardiologických ambulancích u pacientů s CHSS. K výzkumu byl použit standardizovaný „Minnesota Living with Heart Failure Questionnaire“ (MLHFQ). Za účelem komplexního sledování vztahů mezi proměnnými sledovanými v rámci studie byla realizována regresní analýza, avšak v exploračním režimu jako popisná technika, tedy bez ohledu na hodnoty statistické signifikance a bez nároku na zobecňování. Model byl realizován metodou ENTER a naším záměrem bylo zahrnout do něj všechny výše uvedené proměnné. Relativní sílu vlivu pak odhadujeme pomocí standardizovaného koeficientu beta.

Výsledky: Na základě hodnot tohoto koeficientu lze říci, že nejzásadnější vliv na kvalitu života podle MLHFQ má rostoucí stupeň NYHA, dále příslušnost $\mathrm{k}$ invalidům či důchodcům a příslušnost $\mathrm{k}$ mužům. Dodržování léčebného režimu nemá zásadní vliv na kvalitu života, dokonce při jeho větším dodržování dojde k jejímu zhoršení.

Závěr: Pro pacienta s různým stupněm NYHA mohou být léčebné cíle rozdílné. Důležité je, aby si byl vědom, že i když dodržování léčebného režimu zasahuje do jeho kvality života, je toto dodržování nezbytné ke zpomalení progrese tohoto závažného onemocnění.

Klíčová slova: chronické srdeční selhání; kvalita života; MLHFQ; pacient; režimové opatření

\section{References}

1. Abbasi A, Ghezeljeh TN, Farahani MA (2018). Effect of the self-management education program on the quality of life in people with chronic heartfailure: a randomized controlled trial. Electron Physician 10(7): 7028-7037. DOI: 10.19082/7028.

2. Boman K, Olofsson $M$, Bergman AR, Brännström M (2017). Anaemia, but not iron deficiency, is associated with clinical symptoms and quality of life in patients with severe heart failure and palliative home care: A substudy of the PREFER trial. Eur J Intern Med 46: 35-40. DOI: 10.1016/j.ejim.2017.08.027.

3. Buchtová B, et al. (2002). Nezaměstnanost: Psychologický, ekonomický a sociální problém. Praha: Grada.

4. Buleu F, Pah A, Iurciuc S, Iurciuc M, Tudor A, BadalicaPetrescu M, et al. (2019). Vitamin D deficiency, anxiety and depression correlated with quality of life in patients with chronic heart failure. Rom J Cardiol 29(1): 40-46.

5. Bunyamin V, Spaderna H, Weidner G (2013). Health behaviors contribute to quality of life in patients with advanced heart failure independent of psychological and medical patient characteristics. Qual Life Res 22(7): 1603-1611. DOI: 10.1007/ s11136-012-0312-6.

6. Fotos NV, Giakoumidakis K, Kollia Z, Petros G, Copanitsanou P, Pananoudaki E, et al. (2013). Health-related quality of life of patients with severe heart failure. A cross-sectional multicentre study. Scand J Caring Sci 27(3): 686-694. DOI: 10.1111/j.14716712.2012.01078.x.

7. Ghanbari-Firoozabadi M, Rahimianfar AA, Nasab RVM; Namayandeh SM, Emami M, Boostani F, et al. (2014). A study of the effect of cardiac rehabilitation on heart failure patients' life quality. J Med Life 7(1): 51-54.

8. Greenberg BD, Bardard S, Narayan J, Teerlink JR (Eds) (2010). Management of heart failure. Chichester, West Sussex: Wiley.
9. Halmo R, Galuszka J, Langová K, Galuszková D (2015). Self care in patients with chronic heart failure. pilot study - self care includes problems. Biomed Pap Med Fac Univ Palacky Olomouc Czech Repub 159(1): 124-130. DOI: 10.5507/bp.2013.044.

10. Haluzíková J, Hrubá M (2015). Kvalita života pacientů s chronickým srdečním selháním. Cor et Vasa 57(6): 691-696.

11. Heo S, Lennie TA, Pressler SJ, Dunbar SB, Chung ML, Moser DK (2015). Factors associated with perceived control and the relationship to quality of life in patients with heart failure. Eur J Cardiovasc Nurs 14(2): 137-144. DOI: $10.1177 / 1474515113519931$.

12. Hopp FP, Thornton N, Martin L (2010). The lived experience of heart failure at the end of life: a systematic literature review. Health Soc Work 35(2): 109-117. DOI: 10.1093/ hsw/35.2.109.

13. Hradec J, Býma S (2015). Chronické srdeční selhání. Novelizace 2015. [online] [cit. 2019-04-07]. Available from: https://www. svl.cz/files/files/Doporucene-postupy-od-2013/Chronickesrdecni-selhani.pdf

14. Kliková Ch, Kotlán I (2003). Hospodářská politika. Ostrava: Sokrates.

15. Lazárová M, Málek F, Táborský M (2012). Péče o pacienty s pokročilým chronickým srdečním selháním. Interní Med 14(6-7): 246-249.

16. Lewis EF, Johnson PA, Johnson W, Collins C, Griffin L, Stevenson LW (2001). Preferences for quality of life or survival expressed by patients with heart failure. J Heart Lung Transplant 20(9): 1016-1024. DOI: 10.1016/S10532498(01)00298-4.

17. Luo N, O'Connor CM, Cooper LB, Sun JL, Coles A, Reed SD, et al. (2019). Relationship between changing patient-reported outcomes and subsequent clinical events in patients with chronic heart failure: insights from HF-action. Eur J Heart Fail 21(1): 63-70. DOI: 10.1002/ejhf.1299. 
18. Mainardi L, Iazzolino E, Asteggiano R, Lusardi R, Varbella F, Sasso L, Conte MR (2006). Comparison between telephone and outpatient nursing management in patients with chronic heart failure in a large territorial area in Piedmont, Italy. G Ital Cardiol (Rome) 11(1): 35-42.

19. Málek F, Schejbalová M (2011). Chronické srdeční selhání v praxi. Medicína po promoci 2(4): 60-65.

20. Mareš, P. Rabušic L, Soukup P (2015). Analýza sociálně vědních dat (nejen) v SPSS. Brno: Masarykova univerzita.

21. McMurray JJ, Adamopoulos S, Anker SD, Auricchio A, Böhm M, Dickstein K, et al. (2012). ESC Guidelines for the diagnosis and treatment of acute and chronic heart failure 2012. The task force for the diagnosis and treatment of acute and chronic heart failure 2012 of the European Society of Cardiology. Developed in collaboration with the Heart Failure Association (HFA) of the ESC. Eur Heart J 33(14): 1787-1847. DOI: 10.1093/eurheartj/ ehs104.

22. Obiegło M, Siennicka A, Jankowska E, Danel DP (2017). Direction of the relationship between acceptance of illness and health-related quality of life in chronic heart failure patients. J Cardiovasc Nurs 32(4): 348-356. DOI: 10.1097/ JCN.0000000000000365.

23. Rector TS (2017). FDA Medical Device Development Tool (MDDT) Qualification Package for the Minnesota Living with Heart Failure Questionnaire MLHFQ. [online] [cit. 2019-0407]. Available from: https://djhurij4nde4r.cloudfront.net/ attachments/files/000/000/483/original/MLHFQ FDA Medical_Device_Development_Tool_(MDDT)_Qualification_ Package.pdf?1516113948

24. Riedel M (2009). Dějiny kardiologie. Praha: Galén.

25. Slováček L, Slováčková B, Jebavý L, Blažek M, Kačerovský J (2004). Kvalita života nemocných - jeden z důležitých parametrů komplexního hodnocení léčby. Vojenské zdravotnické listy 73(1): 6-9.
26. Soukup, P (2013). Věcná významnost výsledků a její možnosti měření. Data a výzkum - SDA Info 7(2): 125-148. DOI: 10.1306 0/23362391.2013.127.2.41.

27. Šenkyř́iková M (2014). Hodnocení kvality života a informovanosti u pacientů se srdečním selháním. Disertační práce. Brno: LF MU.

28. Špinar J, Vítovec J, Hradec J, Málek I, Meluzín J, Špinarová L, et al. (2012). Czech Society of Cardiology guidelines for the diagnosis and treatment of chronic heart failure 2011. Cor et Vasa 54(2): e113-e134. DOI: 10.1016/j.crvasa.2012.03.002.

29. The Criteria Committee of the New York Heart Association (1994). Nomenclature and criteria for diagnosis of diseases of the heart and great vessels (9th ed.). Boston: Little, Brown \& Co., pp. 253-256.

30. Travis L, Hardin SR, Benton ZG, Austin L, Norris LW (2012). A nurse-managed population based heart failure clinic: Sustaining quality of life. J Nurs Educ Pract 2(4): 1-9. DOI: $10.5430 /$ jnep.v2n4p.

31. Vévodová Š, Andrlová M, Vévoda J (2017). Deprese a kvalita života pacientů s chronickým srdečním selháním. Profese Online 10(1): 15-21. DOI: 10.5507/pol.2017.003.

32. Vojáček J, Kettner J, et al. (2017). Klinická kardiologie. Praha: Maxdorf.

33. Volz A, Schmid JP, Zwahlen M, Kohls S, Saner H, Barth J (2011). Predictors of readmission and health related quality of life in patients with chronic heart failure: a comparison of different psychosocial aspects. J Behav Med 34(1): 13-22. DOI: 10.1007/s10865-010-9282-8.

34. Widimský J, Lefflerová K, Sedláček K (2013). Srdeční selhání. Praha: Triton, 203 p. 